International Journal of Economics, Business and Management Research

Vol. 6, No.01; 2022

ISSN: $2456-7760$

\title{
What Factors Should Be Impacted to Achieve Equality in Income Distribution and Economic Growth at the Same Time? Empirical Analysis From a Group of Countries with Lower-than-average Levels of Inequality and Economic Growth
}

\author{
MSc. Nguyen Thanh Hang \\ Faculty of Development Economics, VNU- University of Economics and Business, \\ Room 709, E4 Building, 144 Xuan Thuy, Cau Giay, Hanoi, Vietnam
}

doi: 10.51505/IJEBMR.2022.6109

URL: http://dx.doi.org/10.51505/IJEBMR.2022.6109

\begin{abstract}
Using estimation of simultaneous equations on data that have been grouped by countries based on both economic development and income inequality in period $1980-2019$, the research has once again confirmed the relationship between income inequality and economic growth in the group of countries with lower than average levels of inequality and economic growth. Growth creates conditions to improve income inequality while moderate income inequality stimulates growth. The research also finds out the impact of a number of factors that are thought to have a impact on both economic growth and income inequality, including: education, health, investment in infrastructure, industrialization, urbanization, globalization, technical progress and inflation. Factors found to favor both growth and income inequality include investment in education and investment in health. From the estimated results, the research has proposed a number of solutions to achieve both economic growth and income equality in this group of countries.
\end{abstract}

Keywords: income inequality, economic growth, system of simultaneous equations,

\section{Introduction}

"How to grow strongly?" is the constant question of all policy makers in all countries of the world. Meanwhile, "How to get an optimal level of inequality?" is not their concern. The way these two issues are viewed and correlated will lead countries to very different futures. The different viewpoints, comparison of the importance of these two issues will lead countries to very different futures. Some people believe that it is necessary to grow at all costs, accept the trade-off of inequality for growth. Others think that these two issues must be resolved simultaneously, not separately. There is another view that it is necessary to deal with inequality first, then progress to growth. This third view was very evident in the socialist countries of the 90s and quickly collapsed after that.

China is a typical example of a "convexo-concave" and unstable fast growth model. Undeniably, most of the time, China has maintained a high growth rate with the highest rate of $13.7 \%$ (1984) and most recently $13.6 \%$ (2007), almost $70 \%$ of the time of achieving growth rate above $7 \%$. However, the instability shown in the growth fluctuation range was very large and in the past 10 years, China's growth has shown signs of slowing down. In general, these are not signs of a healthy economy. In parallel with the growth process, the level of income inequality increased at 


\section{International Journal of Economics, Business and Management Research}

Vol. 6, No.01; 2022

ISSN: $2456-7760$

a rapid rate, from the lowest level of 27.5 (in 1983) to the highest level of 43 (in 2009), decreased slightly and remained at about 42 in the period $2012-2019$. This is a relatively high level in Asia and the world. Although China has been successful in maintaining high growth rates for the period 1977-2007 (30 years), the model is unlikely to work for much longer as China's growth rate has clearly shown a downward trend since 2007. Experience from China shows that, in order to achieve sustainable and long-term economic development, the trade-off of equality for growth is not a good choice.

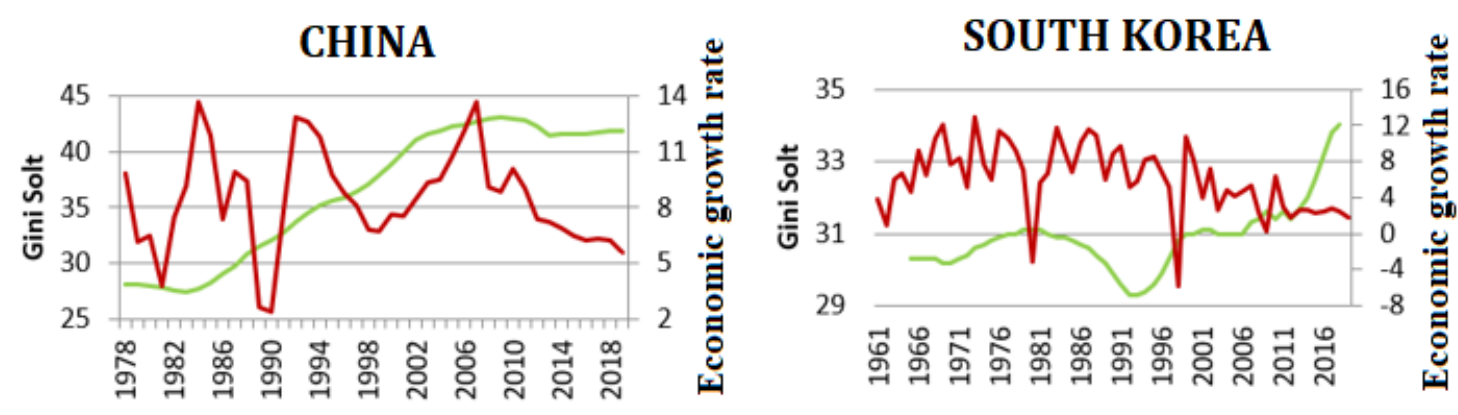

- Gini Solt $\quad$ real GDP per capita growth

Figure 1: GINI coefficient (Sold) and economic growth rate of China in the period 1978 - 2019 and of South Korea in the period 1986 - 2018

Meanwhile, South Korea is a typical example of a stable growth model and social equality. In contrast to China's "convexo-concave" rapid growth, South Korea's growth is steady and seemingly cyclical. In the period 2007 and earlier, compared to other countries, South Korea was one of the few countries with high growth rates compared to the average level while inequality in income distribution was maintained at a low level. short. Since 2007, Korea's growth has been on sideways trend while inequality is increasing at a rapid rate (although still ranked low compared to the world), showing the loosening of Korea in the issue of inequality control, and on the other hand, the risk of restraining growth when inequality is not well controlled. However, Korea's achievements in both equality and efficiency at the same time is an undeniable fact.

Thus, in the long term, choice of stable growth model and social equality should be given priority. Some countries have chosen this path for their national development strategy. In Vietnam, the country's development orientation since the 10th Party Congress has pointed out that "economic growth must be associated with progress and social justice in every development step". So what factors should be implemented to achieve equality in income distribution and economic growth at the same time? The following article will give the answer.

\section{Research Methods}

\subsection{Selection of model and estimation method}

To consider the impact of a certain factor on both inequality and growth, in the context that inequality and growth are believed to be correlated, analysis of each equation separately would be inappropriate. Therefore, this research will use the estimation of simultaneous equations 


\section{International Journal of Economics, Business and Management Research}

Vol. 6, No.01; 2022

ISSN: $2456-7760$

including 1 economic growth equation and 1 income inequality equation. According to Greene (2018), there are 3 commonly used methods to estimate the entire system of equations including 3-stage least squares (3SLS), generalized method of moments (GMM) and full information maximization likelihood (FIML). All three methods use the instrumental variables IVs. For dynamic models, the GMM method is preferred. Because the research take into account the use of lagged variables, the GMM method is chosen.

\subsection{Selection of data}

The data was taken from 1980 to present. One of the reasons for the variation in the results obtained, although in the same research, was due to the heterogeneity of the sample. Observations of very different natures mixed together in a sample could easily skew the estimation results. Therefore, the research conducted to divide the observations into homogeneous subgroups before estimation.

One of the most commonly used grouping methods is based on the level of development ranked by WorldBank. However, this grouping still gives different results because there are countries with low inequality, some countries with high inequality at the same level of development. Therefore, this article has extended the grouping method based on two criteria: (i) the level of economic growth (real GDP per capita) and (ii) the level of income inequality (GINI Sold) of countries. At each year where real GDP per capita is averaged for all countries, the average level of inequality for all countries is established. The countries are then grouped into 4 groups:

Group 1: Group of countries with low growth (lower than average) and low inequality (lower than average)

Group 2: Group of countries with low growth (lower than average) and high inequality (higher than average)

Group 3: Group of countries with high growth (higher than average) and high inequality (higher than average)

Group 4: Group of countries with high growth (higher than average) and low inequality (lower than average)

Based on the results of grouping each year, this research continues to monitor the group change of a country over the years for a long period, thereby ranking that country in the most suitable group according to the following criteria: (i) if in the last 5 years, a country only belongs to group A, it is considered to be in group A for the whole research period; (ii) if in the last 5 years, a country has a change of group, then in the whole period, assuming that country is commonly classified as group A, it belongs to group A. Of these 4 groups, group 1 and group 4 are considered as the group of countries that have chosen to grow with equality while group 2 and group 3 are the group of countries that have chosen the trade-off of equality for growth. Group 3 and group 4 are the successful groups of their choice, and group 1 and group 2 are the unsuccessful groups. Even so, group 1 is said to be in better condition than group 2 and group 4 is in better condition than group 3 . 


\section{International Journal of Economics, Business and Management Research}

Vol. 6, No.01; 2022

ISSN: 2456-7760

Finally, because group 1 is a group of countries that have chosen growth with equality and have not been successful with their choice, this research will focus on group 1, find out what this group of countries needs to do in order to successfully achieve its goal. The list of countries in group 1 is presented in Table 1 and Vietnam belongs to that group.

Table 1: List of countries in group 1

\begin{tabular}{|l|l|l|l|l|}
\hline Afghanistan & Ethiopia & Libya & Pakistan & Kyrgyz Republic \\
\hline Algeria & Hungary & Lithuania & Poland & North Macedonia \\
\hline Armenia & Iraq & Mauritania & Romania & Russian Federation \\
\hline Azerbaijan & Jordan & Mauritius & Serbia & Sao Tome and Principe \\
\hline Bangladesh & Kazakhstan & Moldova & Timor-Leste & Vietnam \\
\hline Belarus & Kosovo & Mongolia & Tonga & West Bank and Gaza \\
\hline Bulgaria & Lao PDR & Montenegro & Turkmenistan & Yemen, Rep. \\
\hline Burundi & Latvia & Myanmar & Ukraine & \\
\hline Cambodia & Lebanon & Nepal & Uzbekistan & \\
\hline Croatia & Liberia & Niger & Venezuela, RB & \\
\hline
\end{tabular}

\section{Proposed Model}

For a long time, the relationship between growth and income distribution has been studied by many scientists. The number of researches on these two issues is relatively large. To identify the factors that affect both income inequality and economic growth at the same time (in the interrelationship between these two factors), the research conducted a literature review, synthesized and presented the results into an analytical framework as shown in Figure 2.

Through the review, factors considered to have an impact on income inequality include: level of economic development (Kuznets, 1955; Barro, 2000), economic growth (Lundberg \& Squire, 2003; Nissim, 2007; Majumdar \& Partridge, 2009; Chambers, 2010; Wahiba \& El Weriemmi, 2014; Huang et al., 2015; Rubin \& Segal, 2015), education (Barro, 2000; Gosling et al., 2000; De Gregorio \& Lee, 2002; Lemieux, 2006), globalization (Barro, 2000; Marrewijk, 2007), government spending on education, health care, infrastructure (Calderon \& Serven, 2004; Chatterjee \& Turnovsky, 2012), tax system (Piketty, 2011; Stiglitz, 2016), industrialization (A. Lewis), urbanization (Kanbur and Zhuang, 2013), technical progress (Erik, 2014; Escap, 2018), imperfect capital markets (Galor \& Zang, 1988), inflation (Cornia, 2004; Easterly \& Fisher, 2001), democracy (Rodrik, 1999; Gradstein \& Milanovic, 2004), corruption (Gupta et al., 2002), social capital (Cook, 2014), and informal sector growth (Adem \& Ceyhun, 2019).

Factors considered to have an impact on economic growth include: investment (Dritsakis, 2004; Meşter \& Simuţ, 2011; Mahmoud, 2012), education (Barro, 2000; Emily, 2012; Kiani, 2013), technical progress (Solow, 1956; Pakko, 2002; Pissarides \& Vallanti, 2006), industrialization (Kaldor, 1967; Szirmai, 1991; Verspagen, 1991; Rodrik, 2009), household consumption (Harbaugh, 1996; Zulkefly et al., 2010), government spending (Barro 1991; Devarajan et al., 1996; Kelly, 1997; Alexiou, 2007), globalization (Mahdavi et al., 2005; Azerbayjani \& Shirani, 2009; Mahmoud, 2012), development of financial markets (Mckinnon, 1973; King \& Levine, 
Vol. 6, No.01; 2022

ISSN: $2456-7760$

1993; Fry, 1995; Ductor \& Grechyna, 2015), inflation (Barro, 1995), urbanization (Spence et al., 2009), institutions (Adam Smith, 1776; Bevan et al., 2004; market economy institutions (North, 1990; Barro, 1991; Fukuyama, 2011; Acemoglu \& Robinson, 2012); corruption (Mauro, 1995); democracy (Rodrik, 2000; Fidrmuc, 2003)), social capital (Coleman, 1988, 1990; Fukuyama, 1995; Dasgupta, 2005; Grootaert \& van Bastelaer, 2002), and informal sector growth (Levy, 2007).

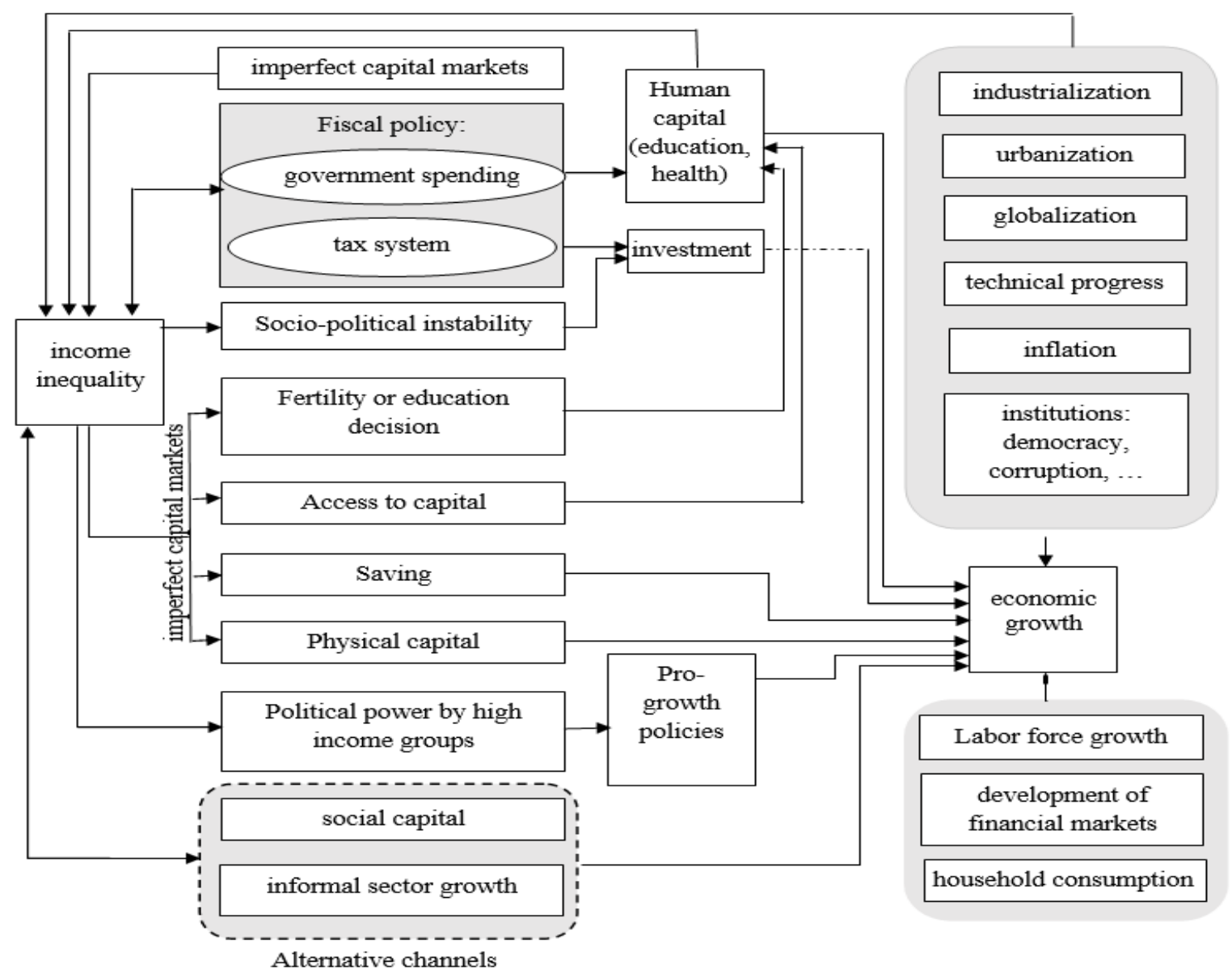

Figure 2: Analytical framework of factors affecting income inequality and economic growth (in the interrelationship between these two factors)

Source: The author

Thus, the factors that are believed to have an impact on both income inequality and economic growth include: industrialization, urbanization, globalization, technical progress, inflation, institutions (democracy, corruption,...), human capital (refers mainly to the role of education, but can also include the role of health), investment (in infrastructure), tax systems, imperfect capital markets, social capital and informal sector growth. Based on the fact of data accessibility, it is necessary to consider ensuring the sample size is reliable enough, the system of equations used to 
estimate (including 1 growth equation and 1 income inequality equation) recommended as below:

$$
\begin{gathered}
G_{t}=\beta_{0}+\beta_{1} G D P_{t-1}+\beta_{2} \text { Ineq }_{t}+\beta_{3} \text { Ineq }_{t}^{2}+\beta_{4} E d u c_{t-10}+\beta X_{1 t}+U_{1 t} \\
\text { Ineq }_{t}=\alpha_{0}+\alpha_{1} G_{t}+\alpha_{2} G_{t}^{2}+\alpha_{3} G D P_{t-1}+\alpha_{4} G D P_{t-1}^{2}+\alpha_{5} E d u c_{t-10}+\alpha X_{1 t}+U_{2 t}
\end{gathered}
$$

In which, $G_{t}$ is economic growth, $G D P_{t}$ is GDP per capita and $I n e q_{t}$ is the level of inequality at time t. $E d u c_{t-10}$ is the enrollment rate of middle school and high school students 10 years ago. $X_{1}$ is a group of control variables, including some or all of the variables that reflect: industrialization, urbanization, globalization, technical progress, inflation, health, and investment in infrastructure. Because a portion of government spending is reflected in spending on education, health care and domestic investment in infrastructure, these are the factors that are expected to improve income inequality while other factors of government spending does not, so government spending will not be included in the regression model as most other studies do. All control variables are taken at the same period as the dependent variable.

\begin{tabular}{|c|c|c|c|}
\hline Variable & Interpretation & Calculation/Source & $\begin{array}{l}\text { Unit of } \\
\text { measure }\end{array}$ \\
\hline G & Economic growth rate & World Development Indicators & $\%$ \\
\hline Ineq & Gini Solt & SWIID 8.3 & $\%$ \\
\hline GDP & Real GDP per capita & World Development Indicators & $\begin{array}{l}\text { Thousand } \\
\text { US\$2010 }\end{array}$ \\
\hline Educ & Gross enrolment ratio, secondary & World Development Indicators & $\%$ \\
\hline Health & $\begin{array}{l}\text { Domestic general government } \\
\text { health expenditure per capita }\end{array}$ & World Development Indicators & US\$ \\
\hline Invest & Gross fixed capital formation & World Development Indicators & $\%$ GDP \\
\hline Internet & $\begin{array}{l}\text { Individuals using the Internet, } \\
\text { representing technical progress }\end{array}$ & World Development Indicators & $\begin{array}{l}\% \text { of } \\
\text { population }\end{array}$ \\
\hline Indus & $\begin{array}{l}\text { Value added of industry (including } \\
\text { construction), representing } \\
\text { industrialization }\end{array}$ & World Development Indicators & $\%$ GDP \\
\hline Urban & $\begin{array}{l}\text { Urban population, representing } \\
\text { urbanization }\end{array}$ & World Development Indicators & $\begin{array}{l}\% \text { of } \\
\text { population }\end{array}$ \\
\hline Exp & $\begin{array}{l}\text { Exports of goods and services, } \\
\text { representing globalization }\end{array}$ & World Development Indicators & $\% \mathrm{GDP}$ \\
\hline $\mathrm{CPI}$ & Inflation & World Development Indicators & $\%$ \\
\hline
\end{tabular}

Table 2: Interpretation of variables used

Note: data was last updated on July 30, 2021. 


\section{International Journal of Economics, Business and Management Research}

Vol. 6, No.01; 2022

ISSN: $2456-7760$

\section{Results and discussion}

Table 3: Estimation results of systems of equations

\begin{tabular}{|c|c|c|c|c|c|c|c|c|c|c|}
\hline & \multicolumn{2}{|l|}{ (1) } & \multicolumn{2}{|l|}{$(2 a)$} & \multicolumn{2}{|l|}{$(2 b)$} & \multicolumn{2}{|l|}{ (3a) } & \multicolumn{2}{|l|}{ (3b) } \\
\hline \multicolumn{11}{|c|}{ Growth equation G } \\
\hline $\mathrm{C}$ & -30.98699 & $* * *$ & -39.54413 & $* * *$ & -26.38817 & $*$ & -13.48081 & & -38.28791 & $* * *$ \\
\hline $\operatorname{GDP}(-1)$ & -0.000205 & $* * *$ & $-7.31 \mathrm{E}-05$ & & -0.00038 & $* * *$ & & & $-3.61 \mathrm{E}-05$ & \\
\hline Ineq & 2.363096 & $* * *$ & 2.786083 & $* * *$ & 2.24946 & *** & 1.543396 & $* *$ & 2.259158 & $* * *$ \\
\hline Ineq $^{2}$ & -0.042571 & $* * *$ & -0.047207 & $* * *$ & -0.041264 & $* * *$ & -0.031739 & $* * *$ & -0.032405 & $* * *$ \\
\hline Educ(-10) & 0.021091 & $* * *$ & 0.024441 & $* * *$ & 0.021556 & $*$ & 0.015851 & $*$ & 0.008557 & \\
\hline Invest & 0.13208 & $* * *$ & 0.132462 & $* * *$ & 0.091285 & $* *$ & 0.064464 & $* *$ & 0.129286 & $* * *$ \\
\hline Indus & 0.025722 & & & & & & & & & \\
\hline CPI & -0.00906 & $* * *$ & -0.006536 & $* * *$ & & & & & & \\
\hline Exp & 0.057912 & $* * *$ & 0.055612 & $* * *$ & 0.056296 & $* * *$ & 0.073961 & $* * *$ & 0.042944 & $* * *$ \\
\hline Urban & -0.049787 & $* * *$ & -0.04443 & $* * *$ & -0.045947 & $* * *$ & -0.037596 & $* * *$ & -0.056853 & $* * *$ \\
\hline Internet & & & -0.027937 & $* * *$ & 0.037386 & $* *$ & & & & \\
\hline Health & & & & & & & -0.008933 & $* * *$ & 0.003037 & $* *$ \\
\hline \multicolumn{11}{|c|}{ Income inequality equation Ineq } \\
\hline $\mathrm{C}$ & 38.66032 & $* * *$ & 40.1745 & $* * *$ & 40.87714 & $* * *$ & 40.16206 & $* * *$ & 38.05771 & $* * *$ \\
\hline $\mathrm{G}$ & -0.798258 & $* * *$ & -0.489366 & $* * *$ & -1.41868 & $* * *$ & -1.407174 & $* * *$ & 0.373833 & $* *$ \\
\hline $\mathrm{G}^{2}$ & 0.017754 & $* * *$ & 0.009398 & $* * *$ & 0.046955 & $* * *$ & 0.037602 & $* * *$ & -0.010633 & \\
\hline $\operatorname{GDP}(-1)$ & 0.001033 & $* * *$ & 0.000731 & $* * *$ & 0.000652 & $* *$ & 0.000749 & $* * *$ & 0.001223 & $* * *$ \\
\hline $\operatorname{GDP}(-1)^{2}$ & $-7.92 \mathrm{E}-08$ & $* * *$ & $-6.97 \mathrm{E}-08$ & $* * *$ & $-7.64 \mathrm{E}-08$ & $* * *$ & $-3.05 \mathrm{E}-08$ & $* * *$ & $-5.57 \mathrm{E}-08$ & $* * *$ \\
\hline Educ(-10) & -0.044804 & $* * *$ & -0.079372 & $* * *$ & -0.032959 & $* *$ & -0.00621 & & -0.076337 & $* * *$ \\
\hline Invest & 0.132143 & $* * *$ & 0.05301 & $* * *$ & 0.084774 & & 0.052139 & $*$ & & \\
\hline Indus & -0.124964 & *** & -0.093597 & $* * *$ & -0.089943 & $* * *$ & -0.083494 & $* * *$ & -0.077016 & *** \\
\hline CPI & -0.010092 & $* * *$ & -0.005059 & $* * *$ & & & -0.041961 & $*$ & & \\
\hline Exp & 0.053891 & $* * *$ & 0.018385 & $*$ & 0.028859 & $*$ & 0.067163 & $* * *$ & & \\
\hline Urban & -0.050458 & $* * *$ & & & -0.041359 & $*$ & -0.039996 & $* *$ & & \\
\hline Internet & & & 0.042689 & $* * *$ & 0.132024 & $* * *$ & & & & \\
\hline Health & & & & & & & -0.016462 & $* * *$ & -0.011169 & *** \\
\hline
\end{tabular}

Note: in the system of equations $2 \mathrm{~b}$, the Internet variable is taken with a lag of 10 years; in the system of equations $3 \mathrm{~b}$, the Health variable is taken with a lag of 10 years. $* * *, * *, *$ : are statistically significant at the $1 \%, 5 \%$ and $10 \%$ levels, respectively.

The estimation results in the group of countries with low economic growth and low inequality (lower than average, group 1) show that:

Economic growth affects income inequality in the form of a U-shaped quadratic function with a parabolic peak at economic growth above 15\%. In fact, most of the growth data of these countries are below 15\%, which means that this relationship is only in a downward direction (approximately an inverse linear relationship) but has not yet reversed to an upward direction. As such, available data indicate that higher growth is accompanied by a decrease in inequality in income distribution. This result reaffirms the view that high growth helps reduce income 


\section{International Journal of Economics, Business and Management Research}

Vol. 6, No.01;2022

ISSN: $2456-7760$

inequality. Higher growth means more accumulation, under the effect of reasonable fiscal policy, more state budget revenue, thereby having more budget to spend on public services such as health care, education, social security and construction and development of infrastructure in rural areas, more equal income distribution. In the opposite direction, income inequality has an impact on economic growth in the form of an inverted U-shaped function with a parabolic peak at income inequality (calculated in Solt) of about 28\%-30\%. Thus, at low levels of income inequality, a increase in income inequality will support economic growth (which corroborates the view that people do not want to be affected by income) while at high levels of income inequality, a increase inequality affects economic growth. In other words, there is an optimal level of income inequality for growth. However, it is difficult to have an optimal level for all countries, depending on the specific characteristics of each different country, this figure may vary.

It is found that an inverted U-shaped relationship between economic growth and income inequality. This result is completely consistent with Kuznets' inverted U-shaped theory, accordingly inequality will increase at an early stage and decrease at a later stage, when the benefits of development are more widely spread. Meanwhile, the estimated results are also consistent with the theory of convergence, countries with a higher level of economic growth have a slower economic growth rate.

Regarding impact of education, the research uses secondary and high school enrollment rates, which finds that with a 10-year lag, education improves income inequality and at the same time promotes economic growth. Education is believed to be able to close the gap between the rich and the poor through creating equality in employment opportunities for the poor, which is supported by De Gregorio and Lee (2002) or Barro (2000). Contrary to the view in 1961, when education was considered as a result of growth, Schultz (1961), one of the pioneers of research on education and economic growth, affirmed that education was also the input of the economy, the investment in human development would bring a relatively high benefit to the society. The positive impact of education on economic growth has been supported by many studies such as Barro (2000), Kiani (2013),

Regarding investment in infrastructure, the research shows that more investment in infrastructure promotes growth but increases the level of income inequality. The positive impact of capital or investment on economic growth has been recognized by many as Dritsakis (2004), Mahmound (2012) or Meşter \& Simuţ (2011). More investment or production capital increase means more factories, equipment, machinery, workshops, new means of transport ... are put into production, thereby helping to increase the productivity of the economy. As one aspect of investment, investment in infrastructure also helps to promote growth. According to Calderon and Serven (2004), public spending, especially spending in investment and development, reduces inequality by improving the poor's access to infrastructure and other public services. Meanwhile, Chatterjee \& Turnovsky (2012) found evidence for the opposite effect of public spending on income inequality. This shows that the beneficiaries have an impact of public spending on income inequality. If public spending is directed towards the poor and disadvantaged in society, helping to improve inequality while public spending is less concerned with the poor and the disadvantaged, exacerbating inequality. Although investment in infrastructure includes both 


\section{International Journal of Economics, Business and Management Research}

Vol. 6, No.01; 2022

ISSN: $2456-7760$

government investment and private investment, its implications are similar. If investment is concentrated in rural infrastructure, it will improve inequality, while if it is concentrated in urban infrastructure, it will increase inequality. The estimated results show that the countries in group 1 are focusing on investing more in urban areas to achieve higher growth while investment in rural infrastructure has not been properly paid attention.

In terms of industrialization, the study discovered that industrialization (as measured by industry value added, \% of GDP) improved inequality, but it had no effect on industrialization on growth. According to A. Lewis, in this early stage of growth, the number of workers being drawn to work in this field is increasing in tandem with the expansion of industrial production scale, but total work pay remains low. As a result, although worker salary remains unchanged, capitalist revenue rises as a result of increased scale and worker labor, resulting in an increase in inequality in a short period of time. Inequality decreases in the latter stages as extra workforce is drawn to metropolitan areas and labor becomes a scarce input in production. The rising demand for workers necessitates a pay raise, which will reduce inequality. However, at a certain degree of growth, the demand for unskilled labor will decline due to the expansion of science and technology and the substitution of machines and equipment with manpower. Significantly, as the demand for skilled labor grows, we will see a return of income inequality, particularly the gap between the highest and lowest quintiles. In the case of group 1 countries, they have gone through a period of scarcity and are at the stage of labor saturation in industrial parks, but they have not yet reached the stage of replacing human power with machines and equipment, so the estimation results show that inequality is decreasing, which is completely consistent. Despite using a variety of regression models, the researchers were unable to find any evidence of the impact of industrialization on growth. Meanwhile, numerous studies have acknowledged the favorable impact of industrialization on economic growth, and there is concrete historical evidence via the industrial revolutions. This effect is significant in developing countries than in advanced economies, where the service sector is gradually growing its contribution. Kaldor (1967), Szirmai (1991), Verspagen (1991) or Rodrik (2009) all agree that industry plays a role as an engine of growth. Industrialization encourages urbanization, economic interdependence, and technological advancement, and it is widely regarded as the most effective strategy to boost the economy's competitiveness. Industrialization has its drawbacks, yet it is undeniable that it has a significant impact on raising productivity and per capita income. In general, a more detailed data study of the influence of industrialization on growth in this group of countries is required.

Inflation is detrimental to growth, but it also helps to reduce inequality, according to research. Economists have reached a relatively broad agreement on the influence of inflation on income inequality. Cornia (2004) claims that inflation will disproportionately harm the poor by diminishing their purchasing power because most of their income comes from salary, while the amount of real assets they accumulate, which are less influenced by price changes, is minimal. Furthermore, the poor have limited access to financial resources to reduce the effects of inflation, as well as insufficient information and awareness (Easterly \& Fisher, 2001). As a result, the amount of inequality appears to be rising in theory. However, because the Sold coefficient is based on the incomes of all five categories, it is unclear whether the middle-class groups (groups 3 and 4) are less affected by high inflation than group 5 (the top $20 \%$ of the population), then it is 


\section{International Journal of Economics, Business and Management Research}

Vol. 6, No.01;2022

ISSN: $2456-7760$

possible that the level of inequality (calculated by the Gini coefficient) will improve despite the fact that the income gap between group 5 and group 1 may increase again. Verification based on the income gap coefficient (the ratio of income of group 5 to group 1) is not within the scope of this paper. Inflation is assumed to have both positive and negative effects on economic growth and there exists a threshold value where mild inflation will have a positive effect on growth (Khan \& Senhadji, 2001). Inflation boosts GDP by encouraging investment, saving, and increased consumption (usually achieved only in the short term). Inflation, on the other hand, has a negative impact on growth due to lower labor productivity, market distortion, a trade deficit, and a long-term loss in investment efficiency. The threshold value is found to vary by country; for example, the threshold value in Vietnam is 3.5 percent. However, negative effects were identified in the majority of situations (Hwang \& Wu, 2011; Bhusal \& Silpakar, 2012), indicating that the analyzed countries (group 1) all have inflation levels that are over the ideal range.

The study found that boosting exports increases growth but also exacerbates inequality. Several research, including Mahmound (2012) and Mahdavi et al (2005), have demonstrated that exports have a favorable effect on growth (2005). Meanwhile, in this group of countries, bustling import and export activity have been observed to enhance income inequality. Because export activities are linked to the demand for skilled workers in this group of countries, the pay difference between skilled and unskilled workers, initially undertaking any kind of labor increases income inequality. An open economy, according to Barro (2000), will exacerbate the gap between the rich and the poor because the wealthy are often better able to take advantage of commercial opportunities. As a result, reducing the detrimental impact of import and export activity on lowincome countries requires a focus on education.

In contrast to the popular belief that urbanization promotes growth, the study found that while rapid urbanization is harmful for growth, it does help to lessen income inequality. The rise of urban areas and the concentration of overpopulation in urban areas cause a slew of social issues that, rather than having a positive impact, will stymie economic growth (more negative than positive). This rapid urbanization process, on the other hand, has provided access to important services for more people, and lowered inequality of opportunity, thereby helping to narrow income inequality.

Although not really accurate, due to data limitations, the study uses the percentage of the population using the Internet as an asymptotic measure for the level of scientific and technological development with the assumption that thigher the percentage of population using the Internet is, the higher the level of scientific and technological development of that country is. As a result, an increase in the share of the population who uses the Internet slows the rate of growth while simultaneously increasing inequality. When looking at the amount of influence from year 10 onwards, an increase in the percentage of the population who uses the internet has a beneficial effect on economic growth, but it still raises inequality. The immediate negative impact of the percentage of the population using the internet on economic growth and the longterm positive impact can be explained as follows: increasing the number of people using the internet requires investment in telecommunications infrastructure, so growth is likely to slow in the short term. People can use the internet for extended periods of time, gaining more 


\section{International Journal of Economics, Business and Management Research}

Vol. 6, No.01;2022

ISSN: $2456-7760$

knowledge, experience, life and work skills, as well as social interactions, and thereby increasing labor productivity and, as a result, increasing growth. We can explain the negative influence on the degree of inequality as follows: the rate of internet usage in these countries is still fairly low. Those who use the internet earn more money than those who do not, resulting in increased income inequality. Only when the percentage of the population who uses the internet reaches a certain level can it help to reduce income inequality.

The study discovered that health slowed growth while increasing inequality. Looking at the impact after 10 years, health aids in the promotion of growth and the reduction of inequality. Increased public spending on health per capita means that the state is more concerned with the overall health of the population, the poor have more opportunities to access health services, their health will be improved, and they have more opportunities to find suitable jobs, improve labor productivity, thereby having the opportunity to earn more income, so inequality is reduced. Having to spend more should result in a short-term drop in growth, but over time, people's health will improve together with increased labor productivity, resulting in a long-term increase in growth.

\section{Conclusions}

The study confirms the reciprocal association between income inequality and economic development once more. Growth facilitates the reduction of income disparity, whereas moderate income inequality promotes growth. Investment in education and health are two factors that have been proven to encourage both growth and income inequality.

The study recommends the following solutions based on the estimated results acquired, so that countries with poor development and low inequality (lower than average) can attain both economic growth and income equality at the same time:

In the short term, education has a negative impact on GDP due to increased spending, while the impact on income equality is insignificant. However, investing in education, which is a vital factor in helping countries achieve long-term economic growth and income equality, must remain a priority. Similarly, while increased health spending slows growth in the short run, it stimulates growth in the long run and has a favorable impact on income inequality, which exists in both the short and long term; consequently, health investment is an essential and long-term solution. We should continue to develop our telecommunications infrastructure, making it easier for more individuals to access the Internet, because of the long-term benefits of Internet usage. The short-term effect of increasing inequality and slowing growth is temporary, but in the long run, when a substantial share of the population uses the internet, it will result in stronger growth and better income equity. To reduce the short-term negative effects of education, health, and internet access on economic growth, policies that encourage growth while preserving income equality should be implemented, as discussed below.

Infrastructure in rural areas should receive more funding. Currently, the results reveal that this group of countries continues to place too much emphasis on metropolitan areas while neglecting rural areas. Better investment in rural infrastructure, while not generating as much growth in the 


\section{International Journal of Economics, Business and Management Research}

Vol. 6, No.01; 2022

ISSN: $2456-7760$

short term as investing in urban areas, contributes to long-term sustainability while also assisting in the reduction of inequality.

Industrialization has helped to reduce inequality while having no influence on growth. Many studies have demonstrated, however, that industrialization has a growth-promoting effect and, to some extent, that industrialization exacerbates inequality. As a result, to enhance growth and reduce inequality, it is vital to take advantage of the temporary good impacts of industrialisation and accelerate industrialization. When industrialisation begins to have a negative impact on income equality, however, contingencies should be taken into account.

While urbanization raises many people's incomes, it has ramifications for growth. As a result, great attention should be given before upgrading an area to an urban area, in order to avoid a hasty upgrade that does not provide the right components for movement.

Although the data show that inflation reduces inequality, it is the Gini coefficient of inequality that is measured, not the income gap between the top $20 \%$ richest and poorest of the population. Because many studies have demonstrated the income gap effect between these two categories, it is critical to keep inflation under control in order to achieve long-term growth and reduce income inequality.

To limit the negative impact of import and export activities on inequality in the group of lowincome countries, export activities should be encouraged while also encouraging investment in education.

\section{References}

1. Acemoglu, D. \& Robinson, J.A. (2012), "Why Nations Fail: The Origins of Power, Prosperity, and Poverty", Crown Publishing, New York.

2. Adem, E., Ceyhun, E. (2019), "Informality, Inequality, and Feminization of Labor", Political Economy Research Institute, University of Massachusetts Amherst, Working Paper No $483,4 / 2019$

3. Alexiou, C. (2007), "Unraveling the "Mystery" between Public Expenditure and Growth: Empirical Evidence from Greece", International Journal of Economics, 1 (1), 21-31.

4. Azerbayjani, K. \& Shirani Fakhr, Z. (2009), "The Impact Of trade and market development on economic growth: case studies Iran and their business partners in the years 1995-2005", Journal of Economic Research of Iran, the Ninth year, No.1

5. Barro, R. J. (1991), "Economic growth in a cross section of countries", The Quarterly Journal of Economics, 106 (2), 407-443.

6. Barro, R.J. (2000), "Inequality and Growth in a Panel of Countries", Journal of Economic Growth, 5, 5-32.

7. Bevan, A., Estrin, S., Meyer, K., (2004), "Foreign Investment Location and Institutional Development in Transition Economies", International Business Review, 13, 43-64. 


\section{International Journal of Economics, Business and Management Research}

Vol. 6, No.01; 2022

ISSN: $2456-7760$

8. Calderon, C. \& Serven, L. (2004), "The effects of infrastructure development on growth and income distribution", Central Bank of Chile, Working Paper No 270.

9. Chambers, D. (2010), "Does a rising tide raise all ships? The impact of growth on inequality", Applied Economics Letters, 17(6), 581-586.

10. Chatterjee, S. \& Turnovsky, S.J. (2012), "Infrastructure and inequality", European Economic Review, 56 (8), 1730-1745.

11. Cornia, G.A. (2004), "Trade liberalization, foreign direct investment and income inequality", Understanding Globalization, Employment and Poverty Reduction, E. Lee and M. Vivarelli (eds.), Palgrave Macmillan, London.

12. De Gregorio, J., \& Lee, J. W. (2002), "Education and income inequality: New evidence from cross-country data", Review of Income and Wealth, 48, 395-416.

13. Devarajan, S., Swaroop, V. and Zou, H. (1996), "The composition of Public Expenditure and Economic Growth", Journal of Monetary Economics, 37, 313- 344.

14. Dritsakis, N. (2004), "Exports, investments and economic development of pre-accession countries of the European Union: an empirical investigation of Bulgaria and Romania", Applied Economics, 36 (16), 1831-1838.

15. Ductor, L. and Grechyna, D. (2015), "Financial development, real sector output, and economic growth", International Review of Economics and Finance, 37, 393-405.

16. Easterly, W. \& Fischer, S. (2001), "Inflation and the Poor", Journal of Money, Credit and Banking, 33, 160-178.

17. Emily (2012), "GDP per capita and labour utisation in Australia", Working Paper 03-12, Department of Industry, Innovation, Science, Research and Tertiary Education.

18. Erik, B. \& Andrew, M. (2014), "The Second Machine Age: Work, Progress, and Prosperity in a Time of Brilliant Technologies", W. W. Norton \& Company.

19. Escap (2018), "Inequality in Asia and the Pacific in the era of the 2030 Agenda for Sustainable Development", https://www.unescap.org/publications/inequality-asia-andpacific-era-2030-agenda-sustainable-development\#

20. Fidrmuc, J. (2003), "Economic Reform, Democracy and Growth during Post-Communist Transition", European Journal of Political Economy, 19, 583-604.

21. Fry, M. J., (1995), "Money Interest, and Banking in Economics Development", Baltimore: Johns Hopkins University Press

22. Fukuyama, F. (2011), "The Origins of Political Order: From Prehuman Times to the French Revolution", Farrar, Straus and Giroux, New York.

23. Galor, O., Zang, H. (1997), "Fertility, income distribution, and economic growth: Theory and cross-country evidence", Japan and the World Economy, 9, 197-229

24. Gosling, A., Machin, S., Meghir, C. (2000). "The Changing Distribution of Male Wages in the U.K", Review of Economic Studies, Oxford University Press, 67(4), 635-666. 


\section{International Journal of Economics, Business and Management Research}

Vol. 6, No.01; 2022

ISSN: $2456-7760$

25. Gradstein, M. \& Milanovic, B. (2004), "Does Liberté = Egalité? A survey of the empirical links between democracy and inequality with some evidence on the Transition Economies", Journal of Economic Surveys, 18 (4), 515-537.

26. Gupta, S., Davoodi, H. \& Alonso-Terme, R. (2002), "Does Corruption Affect Income Inequality and Poverty?", Economics of Governance, 3, 23-45.

27. Harbaugh, R. (1996), "Falling behind the Joneses: relative consumption and the growthsaving paradox", Economic Letters, 53, 297-304.

28. Huang, H. C. R., Fang, W., Miller, S. M., \& Yeh, C. C. (2015), "The effect of growth volatility on income inequality", Economic Modelling, 45, 212-222.

29. Kelly, T. (1997), "Public expenditures and growth", Journal of Development Studies, 34(1), 60-84.

30. Kiani, A.K. (2013). "Education is essential for Economic Growth in Pakistan", African Journal of Business Management, 7(26), 2548-2557, 14 July.

31. King, R.G., Levine, R. (1993), "Finance and Growth: Schumpeter Might Be Right", The Quarterly Journal of Economics, 108, 717-737

32. Kuznets, S. (1955), "Economic growth and income inequality", American Economic Review, $45,1-28$.

33. Lemieux, T. (2006), "Increasing Residual Wage Inequality: Composition Effects, Noisy Data, or Rising Demand for Skill?", American Economic Review, 96 (3), 461-498.

34. Lundberg, M., \& Squire, L. (2003), "The simultaneous evolution of growth and inequality", The Economic Journal, 113(487), 326-344

35. Mahdavi, A. \& Javadi, S. (2005), "Empirically test the relationship between foreign trade and economic growth in Iran", Journal of Economic Research of Iran, the Fifth year, No.23

36. Mahmoud (2012), "The relationships between GDP, Export and Investment: case study Iran", Business Intelligence Journal, 5 (2), 401-405.

37. Majumdar, S., \& Partridge, M. D. (2009), "Impact of economic growth on income inequality: A regional perspective", Paper presented at the Agricultural and Applied Economics Association 2009 AAEA and ACCI Joint Annual Meeting.

38. Marrewijk, C.V. (2007), "International Economics: Theory, Application, and Policy", Oxford University Press, Oxford, U.K., with Study Guide by D. Ottens and S. Schueller. (ISBN 0-19-928098-3 and 978-0-19-928098-8; 691 pages).

39. Mauro, P. (1995), “Corruption and Growth”, Quarterly Journal of Economics, 110 (3), 681712.

40. McKinnon, R. I., (1973), "Money, Capital and Economic Development”, (Washington, D.C: Brookings Institution).

41. Mester, I.T., \& Simut, R.M. (2011), "An Investigation Of Longrun Relationship Between Economic Growth, Investment And Export In Romania", Annals of Faculty of Economics, University of Oradea, Faculty of Economics, 1(1), 316-321, July. 
Vol. 6, No.01; 2022

ISSN: $2456-7760$

42. Nissim, B. D. (2007), "Economic growth and its effect on income distribution", Journal of Economic Studies, 34(1), 42-58.

43. North, D. C. (1990), "Institutions, Institutional Change and Economic Performance", Cambridge University Press, Cambridge.

44. Pakko, M.R. (2002), "Investment SpecificTechnology Growth: Concepts and Recent Estimates", Federal reserve bank of St. Louis Review, 84 (6), 37-48.

45. Piketty, T. (2014), "Le Capital au XXIe siècle”, Éditions du Seuil, French.

46. Rodrik, D. (1999), "Where did all the growth go? External shocks, social conflict and growth collapses", Journal of Economic Growth, 4 (4), 385-412.

47. Rodrik, D. (2000), "Institutions for High-Quality Growth: What They Are and How to Acquire Them", Studies in Comparative International Development, 35 (3), 3-31.

48. Rubin, A., \& Segal, D. (2015), "The effects of economic growth on income inequality in the US", Journal of Macroeconomics, 45, 258-273

49. Smith, A. (1776), Wealth of Nations, W.Strahan, London.

50. Solow, R.M. (1956), "A contribution to the theory of economic growth", The quarterly journal of economics, 70 (1), 65-94.

51. Stiglitz, J.E. (2016), "Inequality and Economic Growth", Rethinking capitalism: economics and policy for sustainable and inclusive growth by Michael Jacobs \& Mariana Mazzucato, 134-155.

52. Wahiba, N. F., \& El Weriemmi, M. (2014), “The relationship between economic growth and income inequality", International Journal of Economics and Financial Issues, 4(1), 135143.

53. Zulkefly, A.K., Bakri, A.K., Riayati, A. (2010), "Fixed investment, household consumption, and economic growth: a structural vector error correction model (SVECM) study of Malaysia", MPRA Paper 27146, University Library of Munich, Germany. 
International Journal of Economics, Business and Management Research

Vol. 6, No.01; 2022

ISSN: $2456-7760$

\section{Annexes}

Table A1: List of countries in other groups

\begin{tabular}{|c|c|c|c|c|}
\hline \multicolumn{5}{|c|}{ Group 2} \\
\hline Albania & El Salvador & Malaysia & South Africa & Bosnia and Herzegovina \\
\hline Angola & Eswatini & Maldives & South Sudan & Burkina Faso \\
\hline Argentina & Fiji & Mali & Sri Lanka & Cabo Verde \\
\hline Barbados & Gabon & Mexico & St. Lucia & Central African Republic \\
\hline Belize & Georgia & Morocco & Sudan & Congo, Dem. Rep. \\
\hline Benin & Ghana & Mozambique & Suriname & Congo, Rep. \\
\hline Bhutan & Grenada & Namibia & Tajikistan & Cote d'Ivoire \\
\hline Bolivia & Guatemala & Nicaragua & Tanzania & Dominican Republic \\
\hline Botswana & Guinea & Nigeria & Thailand & Egypt, Arab Rep. \\
\hline Brazil & Guyana & Palau & Togo & Gambia, The \\
\hline Cameroon & Haiti & Panama & Tunisia & Guinea-Bissau \\
\hline Chad & Honduras & Paraguay & Turkey & Iran, Islamic Rep. \\
\hline Chile & India & Peru & Tuvalu & Micronesia, Fed. Sts. \\
\hline China & Indonesia & Philippines & Uganda & Papua New Guinea \\
\hline Colombia & Jamaica & Rwanda & Uruguay & Solomon Islands \\
\hline Costa Rica & Kenya & Samoa & Vanuatu & $\begin{array}{l}\text { St. Vincent and the } \\
\text { Grenadines }\end{array}$ \\
\hline Comoros & Lesotho & Senegal & Zambia & Trinidad and Tobago \\
\hline Dominica & Madagascar & Seychelles & Zimbabwe & \\
\hline Ecuador & Malawi & Sierra Leone & & \\
\hline \multicolumn{5}{|c|}{ Group 3} \\
\hline Qatar & Puerto Rico & Saudi Arabia & Bahamas, The & Hong Kong SAR, China \\
\hline & & & & St. Kitts and Nevis \\
\hline \multicolumn{5}{|c|}{ Group 4} \\
\hline Andorra & Finland & Italy & Oman & Czech Republic \\
\hline Australia & France & Japan & Portugal & Slovak Republic \\
\hline Austria & Germany & Korea, Rep. & San Marino & Switzerland \\
\hline Belgium & Greece & Kuwait & Singapore & United Kingdom \\
\hline Canada & Greenland & Luxembourg & Slovenia & United States \\
\hline Cyprus & Iceland & Malta & Spain & New Zealand \\
\hline Denmark & Ireland & Netherlands & Sweden & \\
\hline Estonia & Israel & Norway & & \\
\hline
\end{tabular}

